\title{
An examination of Job Satisfaction, Organizational Commitment and Religious Commitment among a Group of Faculty and Administrators in a Christian University
}

\author{
Dr. Samuel Adaboh ${ }^{1}$, Robert Akpalu ${ }^{2}$, Dr. Samuel Stevens Boateng ${ }^{3}$ \\ ${ }^{I}$ Department of Arts and Social Studies Education, School of Education, Valley View University, \\ ${ }^{2}$ Department of Mathematics and Science Education, School of Education, Valley View University \\ ${ }^{3}$ Department of Business Education, School of Education, Valley View University
}

*Corresponding Author: Dr. Samuel Adaboh* Department of Arts and Social Studies Education, School of Education, Valley View University

\begin{abstract}
This paper presents the results of a research study that examined determinants of job satisfaction, among a group of faculty and administrators in a Christian university. With a sample $N=113$ made up of administrators and faculty members, the findings indicated significant differences between administrators and faculty in overall job satisfaction in the areas of achievement, advancement, growth and work itself. The study also indicated that there is no statistically significant difference between the administrators and faculty and their religious and organizational commitments. As the multiple regression analysis to determine how well a linear combination of the 15 measures of job satisfaction predicted organizational commitment, the larger regression model at $F(15,91)=3.88, p<.0001$,found salary $(p=.021)$ as the only significant predictor, whereas a restricted multiple regression result suggest that the strongest predictors of organizational commitment are salary (31.3\%) followed by achievement( $23.8 \%)$ and advancement $(21.4 \%)$.
\end{abstract}

Keywords: Job satisfaction, organizational commitment, religious commitment

\section{INTRODUCTION}

Organizational literature is replete with studies in job satisfaction in work settings, a concern that it shares with disciplines such as psychology, sociology, economics and management sciences. The interest in job satisfaction trends is because of the effect it has on labor market behavior and productivity, work effort, employee absenteeism and staff turnover (Diaz-Serrano \& Viera, 2005; Gazioglu \& Tansel, 2006; Thiruloga sundaram \& Sahu, 2014). Studies in job satisfaction also indicate that organizations have significant effects on the people who work for them and some of these effects are seen in how people feel about their work. Indeed, organizations that have goals to achieve require satisfied and happy work force (Oshagbemi, 2000). This makes job satisfaction an issue of substantial importance to all organizations including universities, which are institutions that provide man power needs to advance national development in both the public and private sectors.

Brown and Sargeant (2007) has pointed out the controversies that still exist between scholars in terms of which intrinsic and extrinsic factors are most prominent in motivating employees and ensuring job satisfaction. This is in spite of the extensive research aimed at unraveling the key issues in job satisfaction. The intrinsic factors identified include; achievement, recognition, the work itself, responsibility and advancement, while the extrinsic factors include; salary, company policies and administrative as well as supervisory practices (Goetz et al., 2012; Baylor, 2012; Herzberg, et al1959). The study sought to find out whether the factors indicated in the literature as predictors of job satisfaction were similar or different in the study context and among the chosen sample.

\section{Purpose}

The purpose of this study was to examine job satisfaction, organizational commitment and religious commitment among a group of faculty and administrators in a university with about 2500 students. Job satisfaction was measured in 15areas: achievement, advancement, growth, recognition, responsibility, work itself, relations with peers, relations with students, relations with supervisors, job security, organizational policy and administration, salary, status, supervision and working conditions. 
An examination of Job Satisfaction, Organizational Commitment and Religious Commitment among a Group of Faculty and Administrators in a Christian University

\section{RESEARCH QUESTIONS AND HYPOTHESES}

The following research questions were addressed in this study

1. How satisfied are faculty and administrators with their jobs?

2. Are the re-significant differences between faculty and administrators in their levels of religious commitment and organizational commitment?

3. Are there age group differences in the levels of religious commitment and organizational commitment?

4. How well does a line are combination of the 15 measures of job satisfaction predict organizational commitment?

The following hypotheses were developed to answer their search questions:

1. H1: Faculty and administrators are equally satisfied with their jobs.

2. H2: There are no statistically significant differences between faculty and administrators in their religious and organizational commitment.

3. H3: There are no age group differences in the levels of religious and organizational commitment.

\section{REVIEW OF LITERATURE}

Previous research indicates that employees who are satisfied with their jobs are more likely to stay with their employers (SHRM, 2009). The determination to keep a cadre of happy and motivated employees has thus become the preoccupation of all organizations aimed a treating their best in the services to their clientele. Interest in issues of job satisfaction thus cut across all disciplines. This view is also shared by Oshagbemi (1996) who believes that job satisfaction is an important subject because of its relevance to the physical and mental well-being of employees. Job satisfaction also affect absenteeism, turnover and job performance. Hence, an understanding of the factors affecting and relating to job satisfaction is important.

Educational researchers have displayed equal attention to issues of job satisfaction. Thompson et al. (1997) cite some research done in job satisfaction in the areas of special education, school psychology, work education, higher education faculty, elementary school teachers, Baldwin (2009), also mentions work done on this in higher education noting how ever that such researchers mainly examined job satisfaction as it relates to academic faculty. He sees job satisfaction as "the extent to which people like (satisfaction) or dislike (dissatisfaction) their jobs". This suggests that job satisfaction is a general or global affective reaction that individuals hold about their job. To Balzer et al. (2000) job satisfaction is "the feelings a worker has about his or her job or job experiences in relation to previous experiences, current expectations or available alternatives" (cited in Baldwin, 2009).Weiss (2002) explains job satisfaction as "a positive (or negative) evaluative judgment one makes about one's job or job situation". Simply, job satisfaction describes show pleased an employee is with his or her position of employment. As the environment in which firms, businesses and institutions operate become increasingly competitive, the level of employee satisfaction takes on added importance.

While researchers and practitioners most of ten measure global job satisfaction, there is also interest in measuring different "facets" or "dimensions" of satisfaction. Examination of these facet conditions is of ten useful for a more careful examination of employee satisfaction with critical job factors. Traditional job satisfaction facets include: co-workers, pay, job conditions supervision, nature of the work and benefits as asserts (Williams2004). There are a number of studies that have identified factors that influence job satisfaction and dissatisfaction (Thomas, 1987; Fraser \& Hodge, 2000; Volkwe in \& Parmley, 2000; Volkwein \& Zhou, 2003; Smerek \& Peterson, 2007, as cited in Baldwin, 2009). Baldwin (2009), further notes specific factors in the literature such as promotion and fringe benefits that influence job satisfaction, and intrinsic and extrinsic factors such as job security, work conditions, achievement and recognition that influence job satisfaction and dissatisfaction. Rosser (2005), asserts that there are some significant factors that determine job satisfaction, namely; rewards and salary, work and career satisfaction, relationship with students, colleagues, administrators and finally benefits and security. 


\subsection{Job Satisfaction}

Spector (1997) has defined job satisfaction as "the extent to which people like (satisfaction) or dislike (dissatisfaction) their jobs."(p. 2). This definition suggests that job satisfaction is a general or global affective reaction that individuals hold about their job. To Balzeret al. (2000) job satisfaction is "the feelings a worker has about his or her job or job experiences in relation to previous experiences, current expectations, or available alternatives" (cited in Baldwin, 2009).Weiss (2002) explains job satisfaction as "a positive (or negative) evaluative judgment one makes about one's job or job situation" (p. 175).Simply put job satisfaction describes how pleased an employee is with his or her position of employment. As the environment in which firms, businesses, and institutions operate become increasingly competitive, the level of employee satisfaction takes on added importance.

While researchers and practitioners most often measure global job satisfaction, there is also interest in measuring different "facets" or "dimensions" of satisfaction. Examination of these facet conditions is often useful for a more careful examination of employee satisfaction with critical job factors. Traditional job satisfaction facets include: co-workers, pay, job conditions, supervision, nature of the work and benefits as asserts Williams (2004). There are a number of studies that have identified factors that influence job satisfaction and dissatisfaction (Thomas, 1987; Fraser \& Hodge, 2000; Volkwein \& Parmley, 2000; Volkwein \& Zhou, 2003; Smerek \& Peterson, 2007, as cited in Baldwin 2009). Baldwin (2009), further notes specific factors in the literature such as promotion and fringe benefits that influence job satisfaction., and intrinsic and extrinsic factors such as job security, work conditions, achievement and recognition, that influence job satisfaction and dissatisfaction. Rosser (2005), asserts that there are four significant areas which determine job satisfaction, namely; rewards and salary, work and career satisfaction, relationship with students, colleagues, administrators and finally benefits and security.

\subsection{Theoretical Foundations of Job Satisfaction}

Brown \& Sargeant, (2007), in a review of the literature on job satisfaction have isolated three theoretical frame works regarding job satisfaction. The first framework is based on content theories of job satisfaction, the second on process theories of job satisfaction and the third on situational models of job satisfaction. The content theories identify specific factors that motivate people to focus on the drivers of human behavior. McGregor's theory X and theory Y, Maslow's hierarchy of needs, Alderfer's ERG (existence, relatedness and growth needs) theory, Herzberg's motivation-hygiene theory and McClelland's theory of needs are some of the content theories. Process theories attempt to explain job satisfaction by looking at expectancies and values (Gruneberg, 1979 citedin Worrell, 2004). This theory suggests that workers' elect their behaviors in order to meet their needs (Adams, 1963; Vroom 1982). To the situational theorists, Quarstein et al. (1992), job satisfaction is determined by situational characteristics and situational occurrences. The situational factors include pay, supervision, working conditions, promotional opportunities and company policies (considered by the employee before accepting a job), and situational occurrences such as extra vacation time, faulty equipment or strained co-worker relationships (occur after getting on the job). The situational theoretical framework states that job satisfaction is a product of both situational factors and situational occurrences.

\subsection{Job Satisfaction in Higher Education}

Job satisfaction of employees in higher education has been an important area of research in recent times Much of the literature, however, have focused more on faculty and staff to the relative neglect of administrators (Baldwin, 2009; Rhodes et al., 2007).Baldwin (2009), has mentioned work done by some researchers such as Volkwein and Zhou (2003), who developed a model of administrative job satisfaction and surveyed nearly 1,178 managers at 122 public and private institutions of higher education. Regarding the job satisfaction of faculty, Baldwin (2009) also mentions Rosser (2004), who while emphasizing on the importance bearing satisfaction has on the faculty members' perceptions of their overall work life, concluded that the quality of the faculty members' work life is important to faculty and affect their overall level of satisfaction. Howell and Hoyt (2007), have also reviewed literature on part time faculty and job satisfaction, noting the paucity of research in this important area of higher education research. Even though they mentioned among others the seminal work of Gappa 
and Leslie (1997) and Schuster and Finkelstein (2006), the impression one gets from their review is that a lot more research is needed in order to capture as accurately as possible the job satisfaction data of this rapidly growing segment of higher education faculty.

\subsection{Organizational Commitment and Higher Education}

In the review of the literature on organizational commitment, Brown and Sargeant (2007) identify it as the relative strength of an individual's identification with and involvement in a particular organization. Such commitment is seen as the binding force of one's loyalty, identification and involvement within an organization and a crucial valuable component in educational institutions. The study of organizational commitment is crucial to researchers and organizations because of the desire to retain a strong workforce. Considerable interest and research have gone into knowing why an individual chooses to stay or leave a job continues to be expressed by such (Tnay et al., 2013). Although, workers' turnover has been found to be related to all three types of commitment (affective, continuous and normative commitment), the literature also suggests there may be unique relationships between the three types of commitment and other work-related outcomes such as absenteeism, organizational citizenship behaviors and performance). Previous researchers have typically focused on organizational outcomes and correlates of commitment. In recent times, however, the research emphasis has been on individual-level correlates of affective commitment like stress, well-being and work-family conflict (Meyer et al. 2002).

Colleges and universities like all organizations, private and public, are interested in retaining their work force and ensuring total commitment to their work. Commitment in higher education as an area of study has identified three broad themes of organizational commitment; an emotional attachment to an organization, the perceived cost associated with leaving the organization and an obligation to remain Gaylor, 2005; Yahaya et al., 2014). In a recent study, Lavakov (2016) examined 317 faculty from Russian universities on the "specific antecedents of affective, normative and continuance commitment of faculty to their university" and concluded "that being an undergraduate inbred (i.e. working at the university from which one graduated) predicted affective and normative commitment toward the university, while having a post at another higher education institution predicted only affective commitment”. (p. 149).

\subsection{Religious Commitment}

Religious commitment can be describe as the commitment a person attaches to their religious teachings in the context of service to which ever organization they belong to. Religious commitment is "derived from a strong sense of meaning and purpose of life, and that derived from belonging to and participating in a fellowship of like-minded believers" (Hadaway \& Roof, 1978, p. 305). To Worthington et al. (2003), religious commitment "is defined as the degree to which a person adheres to his or her religious values, beliefs, and practices and uses them in daily living. The supposition is that a highly religious person will evaluate the world through religious schemas and thus will integrate his or her religion into much of his or her life" (p. 85)

These religious tenets color one's attitude to every experience in life, including how one relates with others. A teacher's basic Christian experience has been considered to be one of the most important criteria of an effective Christian educator (Moore, 1976). Religion and length of organizational tenure have been found to be significant predictors of organizational commitment (Tarr, 1992). Other studies by Rice (1990) and Mancuso (2003) in different faith-based educational settings have indicated a link between ones' faith and practice and commitment to work and the organization.

\section{MATERIALS AND MethodS}

Four hundred survey questionnaires were distributed. Each member of the faculty and administration (i.e., Deans, Department Chairs, Vice Presidents and The President) received the questionnaire via inter-campus mail. One hundred and thirteen completed questionnaires were returned. Participants completed a survey in which 15 areas of job satisfaction were assessed, as well as organizational and 
An examination of Job Satisfaction, Organizational Commitment, and Religious Commitment among a Group of Faculty and Administrators in a Christian University

religious commitment. Each area was assessed along a 5-points scale that ranged from1 (highly dissatisfied/low commitment) to 5(very satisfied/high commitment).

The sample of 113 was made up of administrators and faculty members. Seventy-seven of them were faculty and 36 were administrators. The gender composition of the 87 respondents consisted of 44 males (50.6\%) and 43 females (49.4\%). With regards to the educational level of the sample, $2.7 \%$ had High School diplomas, $19.5 \%$ had a Bachelor's degree and $77.9 \%$ had graduate qualifications at the Master's and Doctoral levels. In looking at gender and the educational attainment of respondents, 9 females had Bachelor's degrees as compared to 6 by males. In terms of graduate education, 36 males had Master's/Doctorate, compared to 34 females having same. The participants who had High School qualifications were male. There were four age groups classified as follows: under $26(n=6), 26-35(n=$ 21), 36-45 $(\mathrm{n}=36)$, and $46+(\mathrm{n}=50)$. Table 1shows the demographic information about the sample.

\section{ANALYSiS}

Table1. Frequency and Percentage of Demographic Characteristics of Sample $(N=113)$

\begin{tabular}{|l|l|l|}
\hline Characteristics & N & \% \\
\hline Occupational Area & \multicolumn{2}{l|}{} \\
\hline Faculty & 36 & 31.9 \\
\hline Administration & 77 & 68.1 \\
\hline Educational Level & \multicolumn{2}{|l|}{} \\
\hline High School & 3 & 2.7 \\
\hline Bachelors & 22 & 19.5 \\
\hline Masters / Doctorate & 88 & 77.9 \\
\hline Gender & 44 & 50.6 \\
\hline Male & 43 & 49.4 \\
\hline Female & \multicolumn{2}{|l|}{} \\
\hline Age Group & 6 & 5.3 \\
\hline Under 26 & 21 & 18.6 \\
\hline $26-35$ & 36 & 31.9 \\
\hline $36-45$ & 50 & 44.2 \\
\hline $46+$ & \multicolumn{2}{|l|}{} \\
\hline
\end{tabular}

Descriptive data such as frequencies and percentage scores were summarized for gender, age, education level, salary and occupational area. This information was used to examine the nature of the sample. In order to address research question one, which sought an answer to the extent of job satisfaction in the occupational areas, an independent t-test was conducted to find out if the administration and faculty members were equally satisfied. Research question two was answered by using a chi-square test to determine the level of organizational and religious commitment. In research question three, the null hypothesis (Ho) which states that there are no statistically significant differences between faculty and administrators in their levels of job satisfaction, religious commitment and organizational commitment was tested. Research question four sought an answer whether there are age group differences in the levels of religious commitment and organizational commitment by comparing three age groups, and for this, a one-way ANOVA procedure was employed. In determining research question five, a multiple regression analysis was performed to answer howthe 15 measures of job satisfaction predicted organizational commitment.

\subsection{Results for Research Question1}

The first research question sought to find out how satisfied faculty and administrators are with their jobs. The null hypothesis formulated to answer the question stated that: There is no statistically significant difference in overall job satisfaction between administrators and faculty. The null hypothesis was tested using the one-way analysis of variance (ANOVA) procedure. The F values for achievement (.030), advancement (.001), growth (.020) and work itself (.035), are smaller than $\alpha=0.05$. We therefore 
An examination of Job Satisfaction, Organizational Commitment and Religious Commitment among a Group of Faculty and Administrators in a Christian University

fail to accept the null hypothesis (Ho). In other words, the extent of differences in job satisfaction between administrators and faculty in these four areas were significantly different. In the other eleven areas of job satisfaction, there were no significant differences (Table 2).

Table2. ANOVA Results Summary

\begin{tabular}{|c|c|c|c|c|c|c|}
\hline $\begin{array}{l}\text { Areas of } \\
\text { Evaluation }\end{array}$ & & \multicolumn{2}{|c|}{ Sum of Squares df } & Mean Square & $\mathbf{F}$ & $\mathbf{p}$ \\
\hline Achievement & $\begin{array}{l}\text { Between Groups } \\
\text { Within Groups } \\
\text { Total }\end{array}$ & $\begin{array}{l}3.734 \\
84.158 \\
87.892\end{array}$ & $\begin{array}{r}1 \\
109 \\
110\end{array}$ & $\begin{array}{l}3.734 \\
0.772\end{array}$ & 4.836 & .030 \\
\hline Advancement & $\begin{array}{l}\text { Between Groups } \\
\text { Within Groups } \\
\text { Total }\end{array}$ & $\begin{array}{l}12.139 \\
119.701 \\
131.841\end{array}$ & $\begin{array}{l}1 \\
111 \\
112\end{array}$ & $\begin{array}{l}12.139 \\
1.078\end{array}$ & 11.257 & .001 \\
\hline Growth & $\begin{array}{l}\text { Between Groups } \\
\text { Within Groups } \\
\text { Total }\end{array}$ & $\begin{array}{l}5.767 \\
115.455 \\
121.221 \\
\end{array}$ & $\begin{array}{l}111 \\
112 \\
\end{array}$ & $\begin{array}{l}5.767 \\
1.040\end{array}$ & 5.544 & .020 \\
\hline Relations- peers & $\begin{array}{l}\text { Between Groups } \\
\text { Within Groups } \\
\text { Total }\end{array}$ & $\begin{array}{l}.948 \\
107.777 \\
108.726 \\
\end{array}$ & $\begin{array}{l}111 \\
112 \\
\end{array}$ & $\begin{array}{l}0.948 \\
0.971\end{array}$ & .977 & .325 \\
\hline $\begin{array}{l}\text { Relations } \\
\text { students }\end{array}$ & $\begin{array}{l}\text { Between Groups } \\
\text { Within Groups } \\
\text { Total }\end{array}$ & $\begin{array}{l}.041 \\
52.959 \\
53.000\end{array}$ & $\begin{array}{l}110 \\
111 \\
\end{array}$ & $\begin{array}{l}0.041 \\
0.481\end{array}$ & .085 & .771 \\
\hline $\begin{array}{l}\text { Relations } \\
\text { Superiors }\end{array}$ & $\begin{array}{l}\text { Between Groups } \\
\text { Within Groups } \\
\text { Total }\end{array}$ & $\begin{array}{l}1.128 \\
112.434 \\
113.563 \\
\end{array}$ & $\begin{array}{l}110 \\
111 \\
\end{array}$ & $\begin{array}{l}1.128 \\
1.022\end{array}$ & 1.104 & .296 \\
\hline Job security & $\begin{array}{l}\text { Between Groups } \\
\text { Within Groups } \\
\text { Total }\end{array}$ & $\begin{array}{l}0.363 \\
162.505 \\
162.867 \\
\end{array}$ & $\begin{array}{l}111 \\
112 \\
112 \\
\end{array}$ & $\begin{array}{r}.363 \\
1.464\end{array}$ & .248 & .620 \\
\hline $\begin{array}{l}\text { Organizational } \\
\text { pol.\& admin }\end{array}$ & $\begin{array}{l}\text { Between Groups } \\
\text { Within Groups } \\
\text { Total }\end{array}$ & $\begin{array}{l}1.743 \\
128.522 \\
130.265 \\
\end{array}$ & $\begin{array}{l}111 \\
112 \\
112 \\
\end{array}$ & $\begin{array}{l}1.743 \\
1.158\end{array}$ & 1.506 & .222 \\
\hline Recognition & $\begin{array}{l}\text { Between Groups } \\
\text { Within Groups } \\
\text { Total }\end{array}$ & $\begin{array}{l}1.176 \\
125.284 \\
126.460\end{array}$ & $\begin{array}{l}1 \\
111 \\
112\end{array}$ & $\begin{array}{l}1.176 \\
1.129\end{array}$ & 1.042 & .310 \\
\hline Responsibility & $\begin{array}{l}\text { Between Groups } \\
\text { Within Groups } \\
\text { Total }\end{array}$ & $\begin{array}{l}0.012 \\
88.222 \\
88.234 \\
\end{array}$ & $\begin{array}{r} \\
109 \\
110 \\
\end{array}$ & $\begin{array}{l}0.012 \\
0.809\end{array}$ & .015 & .903 \\
\hline Salary & $\begin{array}{l}\text { Between Groups } \\
\text { Within Groups } \\
\text { Total }\end{array}$ & $\begin{array}{l}0.236 \\
144.543 \\
144.779 \\
\end{array}$ & $\begin{array}{l}111 \\
112 \\
\end{array}$ & $\begin{array}{l}0.236 \\
1.302\end{array}$ & .181 & .671 \\
\hline Status & $\begin{array}{l}\text { Between Groups } \\
\text { Within Groups } \\
\text { Total }\end{array}$ & $\begin{array}{l}2.527 \\
141.187 \\
143.714\end{array}$ & $\begin{array}{l}110 \\
111 \\
11\end{array}$ & $\begin{array}{l}2.527 \\
1.284\end{array}$ & 1.969 & .163 \\
\hline Supervision & $\begin{array}{l}\text { Between Groups } \\
\text { Within Groups } \\
\text { Total }\end{array}$ & $\begin{array}{l}0.615 \\
131.526 \\
132.142 \\
\end{array}$ & $\begin{array}{l}111 \\
112 \\
112 \\
\end{array}$ & $\begin{array}{l}.615 \\
1.185\end{array}$ & .519 & .473 \\
\hline Work itself & $\begin{array}{l}\text { Between Groups } \\
\text { Within Groups } \\
\text { Total }\end{array}$ & $\begin{array}{l}2.918 \\
71.348 \\
74.265 \\
\end{array}$ & $\begin{array}{l}111 \\
11 \\
112 \\
\end{array}$ & $\begin{array}{l}2.918 \\
.643\end{array}$ & 4.539 & .035 \\
\hline $\begin{array}{l}\text { Working } \\
\text { Conditions }\end{array}$ & $\begin{array}{l}\text { Between Groups } \\
\text { Within Groups } \\
\text { Total }\end{array}$ & $\begin{array}{l}0.966 \\
153.317 \\
154.283 \\
\end{array}$ & $\begin{array}{l}111 \\
112 \\
\end{array}$ & $\begin{array}{l}.966 \\
1.381\end{array}$ & 699 & .405 \\
\hline
\end{tabular}

\subsection{Results for Research Question 2}

The second research question was to find out whether there are significant differences between faculty and administrators in their levels of job satisfaction, religious and organizational commitment. The hypothesis formulated to answer the second research question was $\mathrm{H} 2$ : There are no statistically significant differences between faculty and administrators in the irreligious and organizational commitment. Achi-square test was conducted to test the underlying null hypothesis. Table 3 presents 
An examination of Job Satisfaction, Organizational Commitment, and Religious Commitment among a Group of Faculty and Administrators in a Christian University

the results of the chi-square test between administrators and faculty in organizational commitment, $\chi^{2}$ $(38)=31.49, p=.763$. The effect size was .528. In the case of occupational area (administrators and faculty) and religious commitment, $\chi^{2}(13)=11.69, \mathrm{p}=.554$. The effect size was.322 (Table 4). The null hypothesis was not rejected in that to do so in the case of occupational area and religious commitment will result in $76 \%$ error, and the error will be $55 \%$ in the case of organizational commitment and religious commitment. There is no statistically significant difference between faculty and administrators in their religious and organizational commitment.

Table3.Chi-square test results

\begin{tabular}{|l|l|l|l|l|}
\hline \multicolumn{2}{|l|}{} & Value & df & Asymp. Sig. (2-sided) \\
\hline Organizational & Pearson Chi-Square & $31.494 \mathrm{a}$ & 38 & 0.763 \\
Commitment & Likelihood Ratio & 39.811 & 38 & 0.389 \\
& Linear-by-Linear Assoc. & 3.637 & 1 & 0.057 \\
\hline N of Valid Cases & 113 & \\
\hline Religious & Pearson Chi-Square & $11.686 \mathrm{a}$ & 13 & 0.554 \\
Commitment & Likelihood Ratio & 14.920 & 13 & 0.312 \\
& Linear-by-Linear Assoc. & 5.024 & 1 & 0.025 \\
\hline N of Valid Cases & 113 & & \\
\hline
\end{tabular}

Table4. Symmetric measures

\begin{tabular}{|l|l|l|l|}
\hline & & Value & Approx.Sig. \\
\hline Organizational commitment & Phi & 0.528 & 0.763 \\
& Cramer'sV & 0.528 & 0.763 \\
& No of Valid Cases & 113 & \\
\hline Religious commitment & PhiCramer'V & 0.322 & 0.554 \\
& No of Valid Cases & 0.322 & 0.554 \\
& & 113 & \\
\hline
\end{tabular}

\subsection{Results for Research Question 3}

Research question four sought an answer to whether there are age group differences in the levels of religious commitment and organizational commitment by comparing three age groups of 35 and younger, 36-45, 46 and older. The hypothesis $\left(\mathrm{H}_{3}\right)$ that was formulated to answer this was that there are no age group differences in the levels of religious and organizational commitment. The $\mathrm{F}$ values for the one-way analysis of variance (Table5) for organizational commitment, $\mathrm{F}(3,109)=1.36, \mathrm{p}=.264$ and religious commitment $\mathrm{F}(3,109)=2.32, \mathrm{p}=.079$ are not statistically significant at $\alpha=0.05$. Therefore, the null hypothesis which states that there are no age group differences in the levels of religious and organizational commitment between age groups 35andyounger, 36-45, 46 and older is retained.

Table5. Table of ANOVA

\begin{tabular}{|l|l|l|l|l|l|l|}
\hline & & $\begin{array}{l}\text { Sum of } \\
\text { Squares }\end{array}$ & df & $\begin{array}{l}\text { Mean } \\
\text { Square }\end{array}$ & F & Sig. \\
\hline Organizational Commitment & Between Groups Within Groups 2.308 & 3 & .769 & 1.345 & .264 \\
& Total & 62.345 & 109 & .572 & \\
\hline Religious Commitment & Between Groups & 64.653 & 112 & & & \\
& Within Groups Total & 1.625 & 3 & .542 & 2.323 & .079 \\
& & 25.418 & 109 & .233 & & \\
\hline
\end{tabular}

\subsection{Results for Research Question 4}

In answering research question five which aimed at determining how well a linear combination of the 15 measures of job satisfaction predicted organizational commitment, a multiple regression analysis was conducted. The predictors were; working conditions, relations-students, supervision, organizational policy and administration, advancement, achievement, relations-peers, work itself, salary, recognition, relations-superiors, job security, status, responsibility and growth. In the table of descriptive statistics (Table6) information is provided on the mean, standard deviation, bivariate 
An examination of Job Satisfaction, Organizational Commitment and Religious Commitment among a Group of Faculty and Administrators in a Christian University

correlation and significance (p) between the criterion variable (organizational commitment) and each of the 15 predictor variables. There is a positive correlation between all these predictor variables and the criterion variable within a range of low to moderate positive correlation (.249 to .465). The model summary (Table 7, the R2=.39 indicates that the linear combination of 15 predictor variables account for $39 \%$ of the variance in the criterion variable (organizational commitment).

Table6.Table of Descriptives

\begin{tabular}{|l|l|l|l|l|}
\hline & $N$ & $\mathrm{p}$ & Mean & SD \\
\hline Organizational Commitment & 107 & & 3.7443 & .75429 \\
\hline Achievement & 107 & .000 & 3.7757 & .82769 \\
\hline Advancement & 107 & .000 & 3.3458 & 1.09977 \\
\hline Growth & 107 & .001 & 3.3551 & 1.04838 \\
\hline Relations-peers & 107 & .000 & 3.9252 & .96838 \\
\hline Relations-superiors & 107 & 005 & 3.5794 & 1.01904 \\
\hline Job security & 107 & .000 & 3.4112 & 1.20497 \\
\hline Organizational pol. \& admin & 107 & .000 & 2.8972 & 1.08101 \\
\hline Recognition & 107 & .005 & 3.1682 & 1.07709 \\
\hline Responsibility & 107 & .000 & 3.8972 & .87883 \\
\hline Salary & 107 & .000 & 3.0654 & 1.13496 \\
\hline Status & 107 & .000 & 3.1215 & 1.15506 \\
\hline Supervision & 107 & .001 & 3.4766 & 1.06705 \\
\hline Work itself & 107 & .000 & 3.8879 & .80479 \\
\hline Working Conditions & 107 & .004 & 2.9252 & 1.16312 \\
\hline
\end{tabular}

Table7. Model Summary

\begin{tabular}{|c|c|c|c|}
\hline R & R Square & Adjusted R Square & Std. Error of the Estimate \\
\hline .624 & .390 & 289 & .63588 \\
\hline
\end{tabular}

Table8. Table of ANOVA

\begin{tabular}{|c|c|c|c|c|c|}
\hline & Sum of Squares & df & Mean Square & $\mathrm{F}$ & Sig. \\
\hline $\begin{array}{l}\text { Regression } \\
\text { Residual Total }\end{array}$ & $\begin{array}{l}23.514 \\
36.796 \\
60.310\end{array}$ & $\begin{array}{l}15 \\
91 \\
106\end{array}$ & $\begin{array}{l}1.568 \\
.404\end{array}$ & 3.877 & $.000^{\mathrm{a}}$ \\
\hline
\end{tabular}

The regression model which is shown in Table9 indicates that the linear combination of the job satisfaction predictors and their significance in predicting organizational commitment, $\mathrm{F}(15,91)$ $=3.88, p<.0001$. Salary, $p=.021$ is the only significant predictor, with all the other predictors having $p>$ 0.05 .

Table9: Table of Coefficients

\begin{tabular}{|l|c|c|c|c|}
\hline & \multicolumn{2}{|c|}{$\begin{array}{c}\text { Unstandardized } \\
\text { Coefficients }\end{array}$} & $\begin{array}{c}\text { Standardized } \\
\text { Coefficients }\end{array}$ & Sig \\
\hline & B & Std. Error & Beta & .002 \\
\hline (Constant) $(\mathrm{a})$ & 1.476 & .461 & & .193 \\
\hline Achievement $\left(\mathrm{X}_{1}\right)$ & .126 & .096 & .139 & .154 \\
\hline Advancement $\left(\mathrm{X}_{2}\right)$ & .138 & .090 & .201 & .394 \\
\hline Growth $\left(\mathrm{X}_{3}\right)$ & -.087 & .100 & -.120 & .207 \\
\hline Relations - Peers $\left(\mathrm{X}_{4}\right)$ & .103 & .080 & .132 & .948 \\
\hline Relations - Students $\left(\mathrm{X}_{5}\right)$ & .007 & .113 & .007 & .557 \\
\hline Relations - Superiors $\left(\mathrm{X}_{6}\right)$ & -.049 & .083 & -.066 & .200 \\
\hline Job Security $\left(\mathrm{X}_{7}\right)$ & .092 & .071 & .147 & .366 \\
\hline Organizational Policies \& Administration $\left(\mathrm{X}_{8}\right)$ & .071 & .078 & .102 & .560 \\
\hline Recognition $\left(\mathrm{X}_{9}\right)$ & -.044 & .075 & -.063 & .659 \\
\hline Responsibility $\left(\mathrm{X}_{10}\right)$ & -.047 & .107 & -.055 & .021 \\
\hline Salary $\left(\mathrm{X}_{11}\right)$ & .184 & .078 & .277 & .992 \\
\hline Status $\left(\mathrm{X}_{12}\right)$ & .001 & .078 & .001 & \\
\hline
\end{tabular}


An examination of Job Satisfaction, Organizational Commitment, and Religious Commitment among a Group of Faculty and Administrators in a Christian University

\begin{tabular}{|l|c|c|c|c|}
\hline Supervision $\left(\mathrm{X}_{13}\right)$ & .074 & .086 & .105 & .392 \\
\hline Work Itself $\left(\mathrm{X}_{14}\right)$ & .103 & .098 & .110 & .297 \\
\hline Working Conditions $\left(\mathrm{X}_{15}\right)$ & -.021 & .070 & -.032 & .768 \\
\hline
\end{tabular}

Dependent Variable: Organizational Commitment

Regression Model:

$\mathrm{Y}=\mathrm{a}+\mathrm{b} 1 * \mathrm{X} 1+\mathrm{b} 2 * \mathrm{X} 2+\mathrm{b} 3 * \mathrm{X} 3+\mathrm{b} 4 * \mathrm{X} 4+\mathrm{b} 5 * \mathrm{X} 5+\mathrm{b} 6 * \mathrm{X} 6+\mathrm{b} 7 * \mathrm{X} 7+\mathrm{b} 8 * \mathrm{X} 8+\mathrm{b} 9 * \mathrm{X} 9+\mathrm{b} 10 * \mathrm{X} 10$ $+\mathrm{b} 11 * \mathrm{Xp} 11+\mathrm{b} 12 * \mathrm{X} 12+\mathrm{b} 13 * \mathrm{X} 13+\mathrm{b} 14 * \mathrm{X} 14+\mathrm{b} 15 * \mathrm{X} 15$

A restricted correlation model using salary, achievement and advancement as the most significant of the predictors of organizational commitment is shown in Table 9. With an $\mathrm{R} 2=.34$, one can conclude that $34 \%$ of the variance in the criterion variable (organizational commitment) is due to the three predictors.

Table10.Model Summary (Restricted Model)

\begin{tabular}{|c|c|c|l|}
\hline $\mathrm{R}$ & \multicolumn{1}{|c|}{ R Square } & Adjusted R Square & Std. Error of the Estimate \\
\hline $.580^{\mathrm{a}}$ & .336 & .318 & .62772 \\
\hline
\end{tabular}

Table7. Model Summary (Full Model)

\begin{tabular}{|c|c|c|l|}
\hline \multicolumn{1}{|c|}{$\mathrm{R}$} & R Square & Adjusted R Square & Std. Error of the Estimate \\
\hline $.624^{\mathrm{a}}$ & .390 & 289 & .63588 \\
\hline
\end{tabular}

A comparison of the two model summaries (the full and the restricted models in Tables $7 \& 10$ ) indicate that the three predictors (salary, achievement and advancement), are the most significant in predicting organizational commitment which result in only a 5\%loss in explained variance. Again, the restricted multiple regression results developed from Tables 11 and 12 indicate that the major influence in organizational commitment is salary, achievement and advancement and that the other twelve predictors, though important do not seem to predict organizational commitment to any significant extent. This equation was significant with $\mathrm{R}=.58, \mathrm{R} 2=.34, \mathrm{~F}(3,107)=18.06, \mathrm{p}=0.00$. Although $5 \%$ of the explanation of variance is lost, all three predictors were statistically significant, while the correlation between the measures were moderate. Salary was the strongest predictor (31.3) followed by achievement (23.8) and advancement (21.4). The conclusion can be drawn that approximately $34 \%$ of the variance of organizational commitment can be accounted for by the linear combination of salary, achievement and advancement.

$\mathrm{Y}=1.844+0.203$ Achievement + 0.149Advancement+ 0.210 Salary

Table11.Table of Coefficients (Restricted model)

\begin{tabular}{|l|c|l|c|c|}
\hline & \multicolumn{2}{|c|}{ Unstandardized Coefficients } & Standardized Coefficients & Sig. \\
\hline & B & Std. Error & Beta & \\
\hline (Constant)Achievement & 1.844 & .282 & .238 & .000 \\
Advancement & .203 & .073 & .007 & .016 \\
Salary & .149 & .061 & .315 & .000 \\
\hline
\end{tabular}

Table12.Table of ANOVA

\begin{tabular}{|c|c|c|c|c|c|}
\hline Model & Sum of Squares & $\mathrm{df}$ & Mean Square & $\mathrm{F}$ & Sig. \\
\hline Regression & 21.348 & 3 & 7.116 & 18.060 & $.000^{\mathrm{a}}$ \\
Residual Total & 42.162 & 107 & .394 & & \\
\hline
\end{tabular}

\section{RESULTS AND DISCUSSION}

This study examined job satisfaction, organizational commitment and religious commitment among a group of faculty and administrators in a Christian university. The findings of the first research question indicated significant differences between administrators and faculty in overall job satisfaction in the areas of achievement, advancement, growth and work itself. The F values for achievement (.030,) 
advancement (.001), growth (.020), and work itself (.035), are smaller than $\alpha=0.05$. The ANOVA analysis however, did not indicate any differences in the other eleven areas of job satisfaction. Interpreting this in the context of Herzberg's theory, these four areas of difference between administrators and faculty, and these motivators or job satisfiers are intrinsic in nature. The difference between these occupational factors are thus in intrinsic motivation. These findings seem to be in general agreement with studies by Armstrong (1971), Arthur (1987), Sompong (1990), and Wanous (1974) cited in Brown and Sergeant (2007) which finds differences in intrinsic satisfaction by occupational area.

The study indicated that there is no statistically significant difference between the administrators and faculty and their religious and organizational commitments. The results of the chi-square test between occupational area (administrators and faculty) and organizational commitment was $\chi^{2}(38)=31.49$, $p$ $=.763$. The effect size was .528.In the case of occupational area (administrators and faculty) and religious commitment, it was $\chi^{2}(13)=11.69, p=.554$ at $\alpha=0.05$. This finding go contrary to the study done by Brown and Sargeant (2007) that indicated administrators had the highest level of mean scores of religious commitment by occupational area in the university that they surveyed. The findings also agree with Schroder (2008), who found significant differences in religious commitment between faculty and administrators in a Christian University. Brown and Sargeant (2007), cite Armstrong (1971), Arthur (1987), Sompong (1990) and Wanous (1974), in indicating significant differences in intrinsic job satisfaction among workers by occupational area.

The findings on whether there are age group differences in the levels of religious commitment and organizational commitment by comparing three age groups of 35and younger, 36-45, 46 and older indicated that there were no such differences. The $\mathrm{F}$ values for the one-way analysis of variance for organizational commitment, $\mathrm{F}(3,109)=1.36, \mathrm{p}=.264$ and religious commitment, $\mathrm{F}(3,109)=2.32$, $\mathrm{p}=.079$ are not statistically significant at $\alpha=0.05$. Therefore, the null hypothesis which states that there are no age group differences in the levels of religious and organizational commitment between age groups 35 and younger, 36-45, 46 and older is retained. This finding contradicts Brown and Sargeant (2007) who drew considerable research support from (Angel \& Perry, 1981; Dramstad, 2004; Morris \& Sherman, 1981; Schroeder, 2003; Sheldon, 1971), to support their study that found significant differences among age groups in their study. Their study also indicated that workers who were age 46 years and older were more satisfied with their level of religious commitment than workers who were age 35 years and younger. Their finding appeared consistent with the notion that more mature persons tend to be settled in their religious beliefs. Unlike younger persons who are more likely to be neophytes in their beliefs and are more likely to question the status quo.

The findings of the multiple regression analysis that sought to determine how well a linear combination of the 15 measures of job satisfaction predicted organizational commitment, the larger regression model at $\mathrm{F}(15,91)=3.88, \mathrm{p}<.0001$, found salary $(\mathrm{p}=.021)$ as the only significant predictor, with all the other predictors having $\mathrm{p}>0.05$. A restricted correlation model using salary, achievement and advancement as the predictors was significant, predicting $34 \%$ of the variance in organizational commitment. The restricted multiple regression results suggest that the strongest predictors of organizational commitment are salary (31.3) followed by achievement (23.8) and advancement (21.4).

\section{CONCLUSiON}

The results of this research show that job satisfaction is a multi-dimensional construct and is a product of the global evaluation of one's workplace and context. This study also indicates that both religious and organizational commitment have considerable bearing on job satisfaction. This further provides valuable information on how job satisfactions in both its intrinsic and extrinsic dimensions as well as organizational and religious commitment vary in terms of occupational area (among faculty and administrators). A number of organization specific predictors of job satisfaction were identified as predicting organizational commitment.

The differences between this study and the research literature ought to because for further study and investigation. 


\section{REFERENCES}

[1] Diaz-Serrano, L. \& Cabral Vieira, J.A. (2005). Low pay, higher pay and job satisfaction within the European Union: Empirical evidence from fourteen countries, IZA Discussion Papers No. 1558, Institute for the Study of Labor (IZA), Retrieved at: http://ideas.repec.org/p/iza/izadps/dp1558.html

[2] Gazioglu, S. \& Tansel, A. (2006). Job satisfaction in Britain: Individual and job related factors Applied Economics. 38(10), 1163-1171.

[3] Thirulogasundaram, V. P. \& Sahu, P. C. (2014). Job satisfaction and absenteeism interface in corporate sector: A study. IOSR Journal of Humanities and Social Science (IOSR-JHSS). 19(3), 64-68.

[4] Oshagbemi, T. (2000).Gender differences in the job satisfaction of university teachers". Women in Management Review.15, 331-343.

[5] Brown,D., \& Sargeant, M. A.(2007).Job Satisfaction, organizational commitment, and religious commitment of full-time university employees. Journal of Research on Christian Education, 16, 211-241.

[6] Baldwin, H. T. T.(2009). Administrator job satisfaction in higher education. Retrieved from Pro Quest Dissertations (AAT3394614).

[7] Baylor, K. M. (2012). The influence of intrinsic and extrinsic job satisfaction factors and affective commitment on the intention to quit for occupations characterized by high voluntary attrition. Doctoral dissertation. Nova Southeastern University. Retrieved from NSU Works, H. Wayne Huizenga School of Business and Entrepreneurship. (10). Retrieved from http://nsuworks.nova.edu/hsbe_etd/10

[8] Brown, D., \& Sargeant, M. A.(2007).Job Satisfaction, organizational commitment, and religious commitment of full-time university employees. Journal of Research on Christian Education, 16, 211-241.

[9] The Society for Human Resource Management (SHRM). (2009). Employee job satisfaction: Understanding the factors that make work gratifying. A survey report.

[10] Oshagbemi, T. O. (1996).Job satisfaction of UK academics. Educational Management and Administration. 24(4), 389-400.

[11] Thompson, D. P., Mc Namara,J. F. \& Hoyle,J. R.(1997). Job satisfaction in educational organizations: A synthesis of research findings. Educational Administration Quarterly. 33(1), 7-37.

[12] Weiss, H. M. (2002). Deconstructing job satisfaction: Separating evaluations, beliefs and affective experiences. Human Resource Management Review, 12(2), 173-194.

[13] Williams,J.(2004).Jobsatisfactionandorganizationalcommitment.Retrievedfromhttp://wfnetwork.bc.edu/enc yclopedia_entry.php?id=244

[14] Rosser, V.(2005). Measuring the change in faculty perceptions over time. An examination of their work life and satisfaction. Research in Higher Education, 4(1), 81-107.

[15] Spector, P. E. (1997).Job satisfaction: Application, assessment, causes, and consequences. Thousand Oaks, CA: Sage.

[16] Worrell, T. (2004). School psychologists' job satisfaction: Ten years later. Unpublished doctoral dissertation. Virginia Polytechnic Institute and State University. Blacksburg, Virginia.

[17] Quart stein, V. A., McAfee, B. R., \& Glassman, M. (1992). The situational occurrences theory of job satisfaction. Human Relations. 45(8), 859 - 873

[18] Baldwin, T. T. H. (2009). Administrator Job Satisfaction in Higher Education. Doctoral dissertation. Auburn University. Retrieved from https://etd.auburn.edu/bitstream/handle/10415/1992/Tonia\%20Howard\%20Baldwin\%20Final\%20Dissertat ion\%20Draft.pdf? sequence $=1$

[19] Rhodes, C., Hollinshead, A. \& Nevill, A. (2007). Changing times, changing lives: A new look at job satisfaction in two university schools of education located in the English West Midlands. Research in PostCompulsory Education, 12(1), 7189.

[20] Howell, S. L.\&Hoyt,J.(2007).Part-time faculty job satisfaction in higher education: A literature review. http://www.eric.ed.gov/PDFS/ED499387.pdf

[21] Gappa, J. M.,\& Leslie, D.W. (1993).The invisible faculty: Improving the status of part-timers in higher education. San Francisco: Jossey-Bass.

[22] Schuster, J. H., Finkelstein, M. J. (2006). A Review of the American faculty: The restructuring of academic work and careers. Baltimore, MD: The Johns Hopkins University Press.

[23] Tnay, E., Othman, A. E. A., Siong, H. C. \& Lim, S. L. O. (2013). The influences of job satisfaction and organizational commitment on turnover intention. Procedia - Social and Behavioral Sciences. 97, 201 208.

[24] Meyer, J. P., Stanley, D.J., Herscovitch, L., \& Topolnyutsky, L. (2002). Affective, continuance, and normative commitment to the organization: A meta-analysis of antecedents, correlates and consequences. Journal of Vocational Behavior, 61, 20-52. 
An examination of Job Satisfaction, Organizational Commitment and Religious Commitment among a Group of Faculty and Administrators in a Christian University

[25] Gaylor, K. P. (2005). A comparison of employee-organizational linkages of faculty members at public and private Christian-based colleges. Retrieved from http://www.cbfa.org/Gaylor.pdf

[26] Yahaya, R., Chek, I. T., Samsudin, N., Jizat, J. E. M. \& Yahaya, R. (2014). Organizational commitment at a higher education institution. International Journal of Education and Research. 2(11), 309-318.

[27] Lavakov, A. (2016). Antecedents of organizational commitment among faculty: An exploratory study. Tertiary Education and Management. 22(2), 149-170.

[28] Hadaway, C. K., \& Roof, W. C. (1978). Religious commitment and the quality of life in American society. Review of Religious Research, 19(3), 295-307.

[29] Worthington Jr., E. L., Wade, N., Hight, T. L., Ripley, J. S., McCullough, M. E., Berry, J. W., Schmitt, M. M., Berry, J. T., Bursley, K. H. O’Connor, L. (2003). The religious commitment inventory: Development, refinement, and validation of a brief scale for research and counseling. Journal of Counseling Psychology. 50, 84-96.

[30] Moore, R. S. (1976). Adventist education at the crossroads. Mountain View, CA: Pacific Press.

[31] Tarr, H. C. (1992). The commitment and satisfaction of Catholic school teachers (Doctoral dissertation, The Catholic University of American,1992). Dissertation Abstracts International, 41, 964.

[32] Rice, G. T.(1990). Portrait of Adventist educators: A survey of recent research. The Journal of Adventist Education, 53, 8-15.

[33] Mancuso, A. J. (2003). The motivational aspects for teaching in catholic elementary schools in the diocese of San Jose California: Who teaches in these schools and why? (Doctoral dissertation, University of San Francisco, 2003). Dissertation Abstracts International, 63, 2791.

[34] Schroder, R. (2008). Predictors of organizational commitment for faculty and administrators of a private Christian university. Journal of Research on Christian Education.17 (1),81-97.

\section{AUTHORS' BIOGRAPHY}

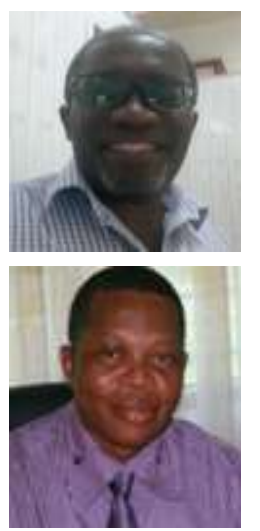

Dr. Samuel Adaboh, He is currently the Head of the Department of Arts and Social Studies Education. He has a $\mathrm{PhD}$ in Curriculum and Instruction and a Masters' degree in Administration in Higher Education. His research interests are in the areas of teaching in higher education, academic programme evaluation and teacher preparation

Robert Akpalu, He holds B.Sc.in Mathematics and M.Phil. in Mathematics Education. His $\mathrm{PhD}$ thesis was in the area of Constructivism. His research interests are: Constructivism, Problem solving and problem posing in Mathematics, Spatial visualization and mathematics learning.

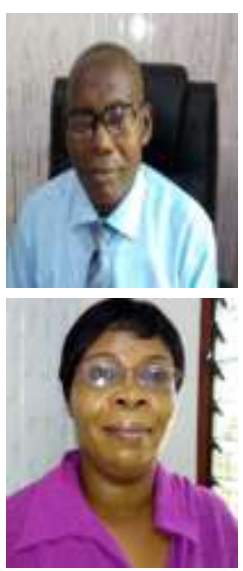

Dr. Samuel Stevens Boateng, He holds a Doctoral degree in Management, and a Masters Degree in Educational Management. His research interests include: Management of human and organizational resources; assessment in teaching, and teaching strategies.

Citation: Dr. Samuel, Adaboh et al. "An Examination of Job Satisfaction, Organizational Commitment, and Religious Commitment among a Group of Faculty and Administrators in a Christian University." International Journal of Humanities Social Sciences and Education (IJHSSE), vol 4, no. 10, 2017, pp. 130-141. doi:http://dx.doi.org/10.20431/2349-0381.0410016.

Copyright: () 2017 Authors. This is an open-access article distributed under the terms of the Creative Commons Attribution License, which permits unrestricted use, distribution, and reproduction in any medium, provided the original author and source are credited. 